\title{
The effect of long-term somatostatin analogue treatment on free and total insulin-like growth factor (IGF) -I, -II and IGF binding protein $-1,-2$ and -3 serum levels in euthyroid patients with active thyroid eye disease
}

\author{
Gerasimos Krassas ${ }^{1}$, Nikolaos Pontikides ${ }^{1}$, Argyrios Dumas ${ }^{2}$, Jan Frystyk ${ }^{3}$, \\ Jian-Wen Chen $^{3}$, Allan Flyubjerg ${ }^{3}$ \\ ${ }^{1}$ Department of Endocrinology and Metabolism, Panagia General Hospital, Thessaloniki, 55132 Greece, \\ ${ }^{2}$ Hippokrates, Nuclear Medicine Center, Thessaloniki, 54622 Greece, ${ }^{3}$ Medical Research Laboratories, \\ Aarhus Kommunehospital, Aarhus University Hospital, Aarhus C., DK-8000 Denmark
}

\begin{abstract}
The aim of this study was to investigate the effect of long-term somatostatin analogue (SM-a) treatment on serum levels of free (F) and total (T) insulin-like growth factor (IGF)-I, -II and IGF binding protein (IGFBP) - 1, -2 and -3 in euthyroid patients with active thyroid ophthalmopathy. For this purpose, we measured the above-mentioned parameters in 21 patients $(11 \mathrm{M}, 10 \mathrm{~F})$, aged $50.8 \pm 11.8$ years (range 35-70) and 19 healthy individuals matched for age, gender and body mass index (BMI). A total of 4 SM-a (sandostatin LAR ${ }^{\circledR}-30$ ) injections, each monthly, were administered in each patient and measurements were performed prior to treatment and 20-30 days after the last injection, while in control individuals the same determinations were performed only once. All patients had active thyroid eye disease (TED), with clinical activity scores (CAS) $\geq 4(5.3 \pm 1.1)$ and positive orbital octreoscan in both eyes. Serum F and T IGF-I and IGF-II were determined using non-competitive, time-resolved monoclonal immunofluorometric assays. IGFBP-1 and IGFBP-2 were determined by an in-house radioimmunoassay, while IGFBP-3 by commercially available IRMA. Our results showed that $\mathrm{F}$ and T IGF-I, -II and IGFBP-1, -2 and -3 levels in patients before and after administration of SM-a were comparable and the levels did not differ significantly from those of controls. Furthermore, no statistically significant differences emerged in the ratio between molar weights of TIGFI/IGFBP-3 and TIGF-II/IGFBP-3, as well as in the ratio of F/TIGF-I and F/TIGF-II in patients before and after SM-a therapy. Fourteen patients (66\%) experienced a decline in CAS of at least $>1$ point in each eye after SM-a administration, whereas in the remaining the CAS did not change. Finally, no relationship was found between the levels of the above-mentioned parameters (post therapy) and CAS, octreoscan scores and thyroid hormones levels. In conclusion, we showed that although SM-a administration in euthyroid patients with active TED had a beneficial effect in a signifi-
\end{abstract}


cant percentage of patients, this effect was not associated with a decline in the circulating IGF-I, -II and IGFBP-1, -2 and -3 levels, at least under the conditions of the present study. It can be postulated that if the mechanism of action of SM-a is through reduction of IGF-I levels, this effect is possibly exerted in the retrobulbar tissues by local paracrine/autocrine action.

Key words: Somatostatin analogue, Thyroid eye disease, IGF-I, IGF-II, IGF binding protein-I, -II, -III

\section{INTRODUCTION}

Thyroid eye disease (TED) or Graves' orbitopathy (GO) or thyroid ophthalmopathy (TO) is an etiologically poorly characterized, inflammatory condition of the orbit, that affects patients with autoimmune thyroid disease $\mathrm{e}^{1,2}$. It occurs in about $50 \%$ of patients with clinically evident Graves' disease ${ }^{3}$ and is severe in about $3 \%$ to $5 \%$ of all cases ${ }^{3}$. Several cytokines, and growth factors including insulin-like growth factor I (IGF-I) and platelet derived growth factor $(\mathrm{PDGF})^{4,5}$, have been detected within the orbital tissues in TED and are now known to be produced both by infiltrating immunocompetent cells and by residential fibroblasts, adipocytes, myocytes and microvascular endothelial cells. These cytokines and growth factors stimulate cell proliferation, glycosaminoglycan (GAG) synthesis and expression of immunomodulatory molecules in orbital fibroblasts and microvascular endothelial cells ${ }^{1,6-8}$. The ensuing increase in connective tissue and extraocular muscle volume within the bony orbit by accumulating hydrophilic compounds, predominantly GAG, contributes to the clinical manifestation of the disease.

Recent pivotal studies of small series of patients have shown successful outcome using therapy with the long-acting somatostatin analogues (SM-a), octreotide $(\mathrm{OCT})^{9}$ and lanreotide (LRT $)^{10}$ in patients with active TED. The exact mechanisms of action of SM-a have not yet been fully clarified. One possible mechanism could be that SM-a suppresses IGF-I activity and through this effect reduces the orbital inflammatory process and its deleterious consequences ${ }^{11}$.

In a recent study ${ }^{12}$ we demonstrated that IGFs (including free fractions) and IGFBPs are not different from controls in euthyroid Graves' patients with active TED.

Due to a lack of longitudinal data, the precise effect of long-term SM-a treatment on serum levels of free and total IGF-I, -II and IGFBP-1, -2 and -3 is unknown. Therefore, this study was undertaken to investigate prospectively free and total IGF-I, -II and IGFBP-1, -2 and -3 levels in euthyroid patients with active Graves' ophthalmopathy undergoing SM-a treatment.

\section{PATIENTS AND METHODS}

Twenty-one euthyroid patients with Graves' disease $(11 \mathrm{M}, 10 \mathrm{~F})$, aged $50.8 \pm 11.8$ years (range $35-70$ ), receiving methimazole therapy (either alone or with thyroxine) for at least 3 months, were evaluated. Euthyroidism was defined as normal values of total thyroxine $\left(\mathrm{TT}_{4}: 75-135 \mathrm{nmol} / \mathrm{L}\right)$ and total tri-iodothyronine $\left(\mathrm{TT}_{3}: 1.1-3.0 \mathrm{nmol} / \mathrm{L}\right)$, with normal or suppressed serum thyrotropin concentration (TSH: $\leq 4.0 \mathrm{mU} / \mathrm{L}$ ). $\mathrm{TT}_{3}, \mathrm{TT}_{4}$ and $\mathrm{TSH}$ were measured by RIA, as previously described ${ }^{9}$. All patients had active thyroid ophthalmopathy, with clinical activity scores (CAS) $\geq 4$ and positive orbital octreoscan in both eyes (Table 1).

Nineteen healthy individuals matched for age, gender and BMI were used as controls for the IGFs and IGFBPs measurements. Patients and healthy individuals were on a similar 'Mediterranean diet'. No female participant was pregnant and none had an intercurrent illness at the time of the study (Table 1).

Four patients were current smokers, 8 ex-smokers, while the remaining 9 never smoked. Eight out of 19 controls were smokers and 3 ex-smokers (Table 1). In all patients serum levels of free and total IGF-I, II, IGFBP-1, -2 and -3 were measured at 9.00 am after an overnight fast before and 20-30 days after the last injection of sandostatin $\mathrm{LAR}^{\circledR}-30$ was given. A total of 4 i.m. injections, each monthly, were administered. In control individuals these measurements were done only once.

\section{Radiopharmaceutical}

The somatostatin derivative (DTPA-D-Phe1)-octreotide prepared by Mallinkrodt Diagnostica (Petten, Holland) was labelled with $244 \mathrm{MBq}(6.6 \mathrm{mCi}){ }^{111} \mathrm{In}$ and injected intravenously. The scintigraphic proto- 
Table 1. Patients' and controls' characteristics, as well as octreoscan and CAS scores results, before and after treatment with SM-a ${ }^{1}$

\begin{tabular}{|c|c|c|c|c|c|}
\hline \multirow[b]{3}{*}{ Age (years) } & \multicolumn{2}{|c|}{$\begin{array}{l}\text { Patients with TED } \\
\qquad(\mathrm{n}=21)\end{array}$} & \multirow[t]{2}{*}{$\begin{array}{l}\text { Control subjects } \\
\qquad(\mathrm{n}=19)\end{array}$} & \multicolumn{2}{|c|}{ P-value } \\
\hline & \multirow{2}{*}{$\begin{array}{c}\text { Before } \\
50.8+11.8\end{array}$} & \multirow[t]{2}{*}{ After treatment } & & & \\
\hline & & & $47.3 \pm 10.4$ & & \\
\hline & $(35-70)$ & & $(32-64)$ & & NS* \\
\hline $\operatorname{Sex}(m: f)$ & $11: 10$ & & $10: 9$ & & \\
\hline \multirow[t]{2}{*}{ Body Mass Index $\left(\mathrm{Kg} / \mathrm{m}^{2}\right)$} & $27.4 \pm 3.8$ & $27.2 \pm 3.6$ & $26.7 \pm 3.6$ & $\mathrm{NS}^{+}$ & NS \\
\hline & $(22.1-34.5)$ & $(22.0-33.5)$ & $(21.9-35.1)$ & & \\
\hline Total $\mathrm{T}_{4}(\mathrm{nmol} / \mathrm{L})$ & $98.9 \pm 13.4$ & $95.4 \pm 11.9$ & $93.6 \pm 14.7$ & NS & NS \\
\hline Total $\mathrm{T}_{3}(\mathrm{nmol} / \mathrm{L})$ & $1.9 \pm 0.4$ & $1.7 \pm 0.5$ & $2.1 \pm 0.4$ & NS & NS \\
\hline $\mathrm{TSH}(m U / L)$ & $1.6 \pm 0.4$ & $1.9 \pm 0.5$ & $1.3 \pm 0.3$ & NS & NS \\
\hline \multirow[t]{2}{*}{ Octreoscan score (mean of both eyes) } & $1.82 \pm 0.12$ & & & & \\
\hline & $(1.47-2.32)$ & & & & \\
\hline \multirow[t]{2}{*}{ Clinical Activity Score } & $5.3 \pm 1.1$ & $3.0 \pm 1.1$ & & $\mathrm{P}<0.001$ & \\
\hline & $(4-7)$ & $(2-5)$ & & & \\
\hline Current smokers & 4 & & 8 & & \\
\hline Ex-smokers & 8 & & 3 & & \\
\hline Never smoked & 9 & & 8 & & \\
\hline
\end{tabular}

$N S=$ not significant. Values are mean $\pm S D$ with ranges in parentheses, TED: Thyroid eye disease

${ }^{+}=$Patients before vs patients after SM-a treatment

* = Patients before vs control individuals

1. Adopted from Krassas GE, et $\mathrm{al}^{12}$ by the permission of the Endocrine Society

col and quantitation method have been reported in detail elsewhere ${ }^{9-11,13}$. Briefly, a previously described stereotaxic technique for slice selection was adopted ${ }^{14}$. The transaxial images were standardized to yield a constant number of 16 slices (12 mm thick per slice) for all SPECT studies. Using a mid-line sagital slice for better localization of the orbital area, five transaxial slices were chosen for quantitation, covering all the orbital and periorbital area.

Semiquantitative analysis. SM receptor binding was measured semiquantitatively by calculating for each subject both at the 4-h and 24-h acquisition the orbital-to-skull counts ratio in all the ten slices at both the 4-h and 24-h acquisition. All ratios were expressed as mean pixel count ratios for the two phases of the examination.

\section{Clinical Activity Score}

A disease activity score was calculated by assigning one point for the presence of each of the following signs and symptoms: spontaneous retrobulbar pain, pain on eye movements, eyelid erythema, conjuncti- val injection, chemosis, swelling of the caruncle and eyelid oedema or fullness. The sum of these points (range 0-7) defines the $\mathrm{CAS}^{15}$.

\section{Free and total IGF-I and -II}

Serum free and total IGF-I and IGF-II were determined after acid-ethanol extraction using non-competitive time-resolved monoclonal immunofluorometric assays, as previously described ${ }^{16}$. All samples were measured in one assay. The within and in-between assay CVs for this assay are below 5 and $10 \%$, respectively. Serum free IGF-I and IGF-II were determined using ultrafiltration by centrifugation, as previously described ${ }^{17}$. Amicon YMT 30 membranes and MPS-1 supporting devices were used (Amicon Division, Beverly, MA, USA). Before centrifugation, serum samples were diluted (1 in 11) in Krebs-Ringer bicarbonate buffer ( $\mathrm{pH} 7.4$ ) containing $50 \mathrm{~g} / \mathrm{l}$ human serum albumin (Behring AG, Marburg, Germany). From each dilution, triplicates of $600 \mathrm{ml}$ were applied to the membranes and incubated $\left(30 \mathrm{~min}\right.$ at $\left.37^{\circ} \mathrm{C}\right)$ and centrifuged $\left(1500 \mathrm{rpm}\right.$ at $37^{\circ} \mathrm{C}$; model Rotixa/RP; 
Hettich Zentrifugen, Tuttlingen, Germany). The lower detection limit of free IGF-I and -II in the ultrafiltrates was 20 and $90 \mathrm{ng} / \mathrm{l}$, respectively. Including ultrafiltration and immunoassay, the within assays of CV averaged $18 \%$ and $12 \%$ for free IGF-I and -II, respectively.

\section{IGFBP-1, IGFBP-2 and IGFBP-3 assays}

IGFBP-1 was determined by an in-house radioimmunoassay (RIA) performed as described by Westwood et $\mathrm{al}^{18}$ with modifications, as described previously $^{12}$. The within and in-between assay CVs averaged less than 5 and $16 \%$, respectively.

IGFBP-2 was determined by a novel in-house TRIFMA based on reagents from R\&D Systems (Abingdon, UK), as described previously ${ }^{12}$. The within and in-between assay CVs are 5 and $12 \%$, respectively.

Serum IGFBP-3 was measured by commercially available IRMA (Diagnostic System Laboratories Inc., Webster, Texas, USA). The within and in-between assay CVs for this assay are below 5 and $10 \%$, respectively.

\section{Statistical analysis}

All data are expressed as mean \pm SD. Normal dis- tribution of all parameters was tested by the Kolmogorov-Smirnov test. Statistical analysis was performed by unpaired two-tailed Student's t-test and regression analysis. Two-sided $\mathrm{p}<0.05$ was considered significant.

\section{RESULTS}

As shown in Table 2, free and total IGF-I and -II and IGFBP-1, -2 and -3 levels were comparable in patients with active TED before and after treatment with SM-a. The same was true when those results were compared with controls. In addition, no significant differences were observed in the molar ratio between total IGF-I, -II and IGFBP-3 as well as in the ratio of free to total IGF-I and free to total IGF-II. Mean CAS was $5.3 \pm 1.1$ before treatment and decreased to $3.0 \pm 1.1(2-5)$ after treatment $(\mathrm{p}<0.001)$ (Table 1). Mean octreoscan score was $1.82 \pm 0.12$. Fourteen patients $(66 \%)$ experienced a decline in CAS (Figure 1) of at least $>1$ mark in each eye after SM-a administration (responders), while the CAS did not change in the rest (non-responders). No patient deteriorated. The above-mentioned parameters did not differ in the two subgroups, i.e. responders vs non-responders. Thyroid hormone levels, as well as BMI, did not change after treatment (Table 1). Finally, no relation-

Table 2. Free and total IGF-I and -II, as well as IGFBP-1, -2 and -3 results in euthyroid patients with active TED undergoing SM-a treatment $(\mathrm{Rx})$ and in controls.

\begin{tabular}{lccccc}
\hline & $\begin{array}{c}\text { Patients } \\
\text { Before Rx } \\
\mathrm{n}=21\end{array}$ & $\begin{array}{c}\text { After Rx } \\
\mathrm{n}=20\end{array}$ & $\begin{array}{c}\text { Controls } \\
\mathrm{n}=19\end{array}$ & \multicolumn{2}{c}{ P-value } \\
\hline Free (F) IGF-I $(\mu g / L)$ & $0.67(0.46)$ & $0.64(0.44)$ & $0.85(0.43)$ & $0.43^{+}$ & $0.70^{*}$ \\
Total (T) IGF-I $(\mu g / L)$ & $131(61)$ & $126(55)$ & $146(51)$ & 0.29 & 0.96 \\
F IGF-II $(\mu g / L)$ & $1.45(0.54)$ & $1.52(0.76)$ & $1.53(0.53)$ & 0.75 & 0.94 \\
T IGF-II $(\mu g / L)$ & $1056(300)$ & $1092(310)$ & $939(197)$ & 0.77 & 0.11 \\
IGFBP-1 $(\mu g / L)$ & $33(14)$ & $45(31)$ & $44(24)$ & 0.07 & 0.09 \\
IGFBP-2 $(\mu g / L)$ & $848(377)$ & $903(409)$ & $764(316)$ & 0.58 & 0.28 \\
IGFBP-3 $(\mu g / L)$ & $3953(1422)$ & $3981(1369)$ & $3721(1017)$ & 0.48 & 0.12 \\
${ }^{\circledR}$ T IGF-I/IGFBP-3 $(\%)($ molar ratio) & $18.1(23.3)$ & $17.3(21.9)$ & $21.4(27.3)$ & 0.25 & 0.62 \\
${ }^{*}$ T IGF-II/IGFBP-3 $\%$ (molar ratio) & $145.7(115.1)$ & $149.6(123.5)$ & $130.0(106.7)$ & 0.31 & 0.36 \\
F/T IGF-I $(\%)$ & $0.47(0.16)$ & $0.48(0.23)$ & $0.61(0.28)$ & 0.97 & 0.18 \\
F/T IGF-II $(\%)$ & $0.19(0.19)$ & $0.18(0.18)$ & $0.16(0.07)$ & 0.78 & 0.22 \\
\hline
\end{tabular}

$\&=$ The molar weight of IGFBP- 3 is $42 \mathrm{KDa}$, and that of IGF-I and -II $7.7 \mathrm{KDa}$. Thus, to achieve the molar ratio, we calculated the molar concentrations of IGFBP-3 $(=\mu \mathrm{g} / 1 / 42 \mathrm{nmol} / \mathrm{l})$ and molar concentrations of IGF-I, $-\mathrm{II}(=\mu \mathrm{g} / 1 / 7.7 \mathrm{nmol} / \mathrm{l})$

${ }^{+}=$Patients before vs patients after SM-a treatment

$*$ = Patients before vs controls individuals

The data before therapy in patient and those of controls are adopted from Krassas GE, et a ${ }^{12}$ by the permission of the Endocrine Society 


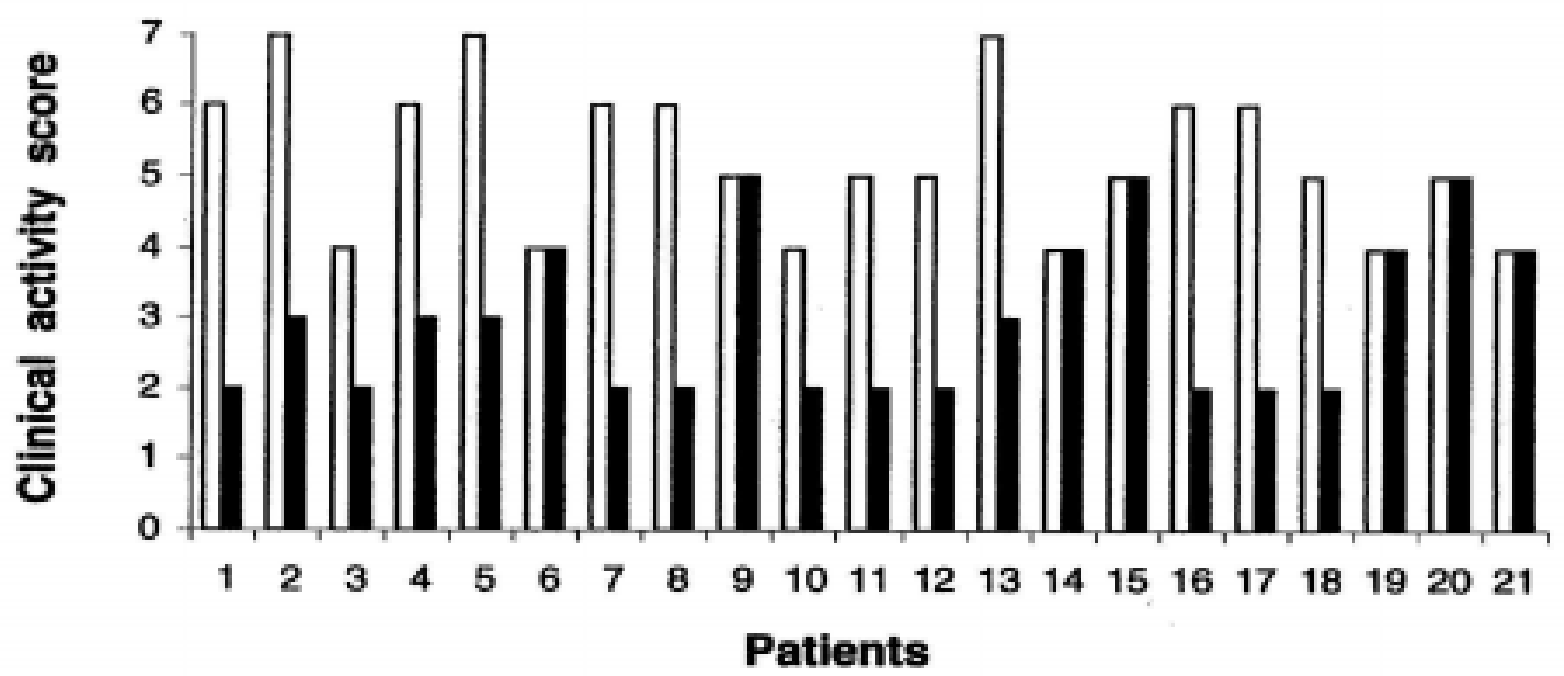

Figure 1. Clinical activity scores (mean of the measurements in both eyes) in each patient before somatostatin analogue (sandostatin LAR $^{\circledR}-30$ ).

ship was found between the levels of the above-mentioned parameters and CAS, octreoscan scores and thyroid hormones.

The base line values of the different parameters measured in our patients were previously reported ${ }^{12}$.

\section{DISCUSSION}

Our results demonstrate for the first time that longterm SM-a treatment in euthyroid patients with active thyroid eye disease has no effect, either on free IGF-I, -II and total IGF-I, -II or on IGFBP-1, -2 and -3 serum levels.

These data are in disagreement with those reported by Khoo et al ${ }^{19}$, who measured only total IGF-I levels in 8 patients before and after 8 weeks' treatment with octreotide. They found an IGF-I decrease after treatment but there was no correlation between the reduction and clinical improvement. In their study no details for the IGF-I assay were given, and some of the patients were not euthyroid on the basis of the $\mathrm{FT}_{4}, \mathrm{TT}_{3}$ and TSH results provided. An alternative interpretation of the discrepancy could be a transient decline of IGF 1 level which is followed by an escape phenomenon later on, since our post measurements were made at about week 24 .

In diabetics with proliferative or preproliferative retinopathy, Hyer et $\mathrm{al}^{20}$ found that octreotide given as a continuous sc infusion via a portable pump or as thrice daily sc injections results in a significant decrease of IGF-I levels. No similar study has been done so far in patients with TED.

In 1986, Hansson et $\mathrm{al}^{21}$ reported that IGF-I levels were elevated in samples of eye muscle and fat, which were obtained after a decompression surgery from 2 patients with active thyroid ophthalmopathy. In 1989, Hansson $^{22}$ also reported intense IGF-I immunoreactivity at medial rectus muscle cells, fat cells and retrobulbar inflammatory cells in biopsy specimens from retrobulbar tissue from 6 patients with malignant exophthalmos. It was suggested that the inflammatory process is the cause of the local high IGF-I formation, which finally acts in an autocrine and/or paracrine manner. In a recent study we demonstrated that serum levels of IGFs and IGFBPs in such patients are normal, although IGF-I levels are implicated in the possible mechanism of action of SM-a in this disease ${ }^{12}$.

The SM-analogues used so far (octreotide and lanreotide) have been shown to have a beneficial effect in patients with TED ${ }^{9-11}$. To our knowledge, no previously published studies have used sandostatin LAR ${ }^{\circledast}$ 30 in such patients. The exact mechanism of action of $\mathrm{SM}-\mathrm{a}$ has not yet been fully clarified. One possible mechanism of SM-a action is suppression of IGF-I levels. Inhibition of IGF-I mediated effects may be a promising strategy for controlling the orbital inflammatory process and its deleterious consequences ${ }^{21}$. Moreover, recent data have demonstrated that orbit- 
al lymphocytes and fibroblasts from patients with active TED express somatostatin receptors and they are targeted by SM-analogues, which could explain the therapeutic effect of SM analogues in such patients ${ }^{23,24}$. Therefore, the beneficial effects of SM-a on TED may be due to the direct action of the drug on retrobulbar cells together with the effect mediated by inhibition of the local immune system ${ }^{24}$.

On the basis of our results it can be assumed that IGF-I, which is produced locally in retrobulbar tissues from patients with active TED ${ }^{21,22}$, is independent of serum IGF-I concentration and probably represents autocrine and/or paracrine action. Furthermore, if one possible mechanism of action of SM-a is by suppression of IGF-I activity, this must be achieved locally by reducting IGF-I synthesis. An interesting question is why SM-a fail to reduce IGF-I in these patients. Presumably the hypothalamic/pituitary/IGF-I axis has the ability to escape and thus compensate in people whose axis is not disturbed by autonomous GH secretion. Another explanation is that after the SM-a an early drop in IGF-I is achieved, followed by return to normality: such a phenomenon could not be ascertained by the design of our study. Following an intramuscular injection of sandostatin-LAR ${ }^{\circledR}$, octreotide levels rise briskly (within $2 \mathrm{~h}$ ), reflecting the release of octreotide from the surface of the microspheres. Subsequently, levels rapidly subside, remaining low for the first seven days after injection, rise again between days 7 and 14 and remain constantly elevated for 28-42 days $^{25}$. On the basis of these data the maximum effect of the drug is expected on the various IGF-related parameters to be in the second half of the month. Finally, the lack of IGF-I reduction could be due to the relatively low sandostatin-LAR ${ }^{\circledR}-30$ dose used, which affects the eye disease but has no systematic effect. Further studies are needed to examine retrobulbar IGF-I immunoreactivity before and after administration of SM-a, and at possibly more frequent intervals in the periphery before final conclusions can be reached.

\section{ACKNOWLEDGEMENTS}

We would like to thank Dr. Petros Perros, Consultant Physician and Endocrinologist at Freeman Hospital, Newcastle UK for his valuable comments and suggestions, and Ms Anna Gialantzi, Kirsten Nyborg, Joan Hansen and Susanne Sorensen for their excellent secretariat and technical assistance.

\section{REFERENCES}

1. Burch HB, Wartofsky L, 1993 Graves' ophthalmopathy: current concepts regarding pathogenesis and management. Endocr Rev 14: 747-793.

2. Bahn RS, Heufelder AE, 1993 Pathogenesis of Graves' ophthalmopathy. N Engl J Med 329: 1468-1475.

3. Jacobson DH, Gorman CA, 1984 Endocrine ophthalmopathy: current ideas concerning etiology, pathogenesis and treatment. Endocr Rev 5: 200-220.

4. Baxter RC, 1986 The somatomedins: insulin-like growth factors. Adv Clin Chem 25: 49-115.

5. Imai Y, Odajima R, Inove Y, Shishiba Y, 1992 Effect of growth factors in hyaluran and proteoglycan synthesis by retroocular fibroblasts of Graves' ophthalmopathy in culture. Acta Endocrinol 126: 541-552.

6. Heufelder AE, 1995 Pathogenesis of Graves' ophthalmopathy. Recent controversies and progress. Eur J Endocrinol 132: 532-541.

7. Heufelder AE, Scriba P, 1996 Characterization of adhesion receptors on cultured microvascular endothelial cells derived from the retro-orbital connective tissue of patients with Graves' ophthalmopathy. Eur J Endocrinol 134: 5160.

8. Metcalfe RA, Weetman AP, 1994 Stimulation of extraocular muscle fibroblasts by cytokines and hypoxia: possible role in thyroid-associated ophthalmopathy. Clin Endocrinol 40: 67-72.

9. Krassas GE, Dumas A, Pontikides N, Kaltsas Th, 1995 Somatostatin receptor scintigraphy and octreotide treatment in patients with thyroid eye disease. Clin Endocrinol 42: 571-580.

10. Krassas GE, Kaltsas Th, Dumas A, Pontikides N, Tolis G, 1997 Lanreotide in the treatment of patients with thyroid eye disease. Eur J Endocrinol 136: 416-422.

11. Krassas GE, 1998 Somatostatin analogues in the treatment of thyroid eye disease. Thyroid 8: 443-445.

12. Krassas GE, Pontikides N, Kaltsas Th, et al, 2002 Free and total insulin-like growth factor (IGF) -I, -II and IGF binding protein $-1,-2$ and -3 serum levels in patients with active thyroid eye disease. J Clin Endocrinol Metab 88: 132-135.

13. Krassas GE, Kahaly GJ, 1999 The role of octreoscan in thyroid eye disease. Eur J Endocrinol 140: 373-375.

14. Ichise M, Toaym H, Vines DC, Chung DG, Kirsch JC, 1992 Neuroanatomical localization for clinical SPECT perfusion brain imaging: a practical proportional grid method. Nucl Med Commun 13: 861-866.

15. Anonymous, 1992 Thyroid 2: 235-236.

16. Frystyk J, Dinesen B, Orskov H, 1995 Non-competitive time-resolved immunofluorometric assays for determination of human insulin-like growth factor I and II. Growth Reg 5: 169-176.

17. Frystyk J, Skjærbæk C, Dinesen B, Orskov H, 1994 Free insulin-like growth factors (IGF-I and IGF-II) in human serum. FEBS Lett 348: 185-191.

18. Westwood M, Gibson JM, Davies AJ, Young RJ, White A, 1994 The phosphorylation pattern of insulin-like 
growth factor-binding protein-1 in normal plasma is different from that in amniotic fluid and changes during pregnancy. J Clin Endocrinol Metab 79: 1735-1741.

19. Khoo DHC, Tan YT, Fok ACK, Tan CE, 1995 Octreotide in the management of Graves' ophthalmopathy - changes in insulin-like growth factor 1 levels do not predict clinical response. Am J Clin Research 4: 33-42.

20. Hyer L, Sharp PS, Brooks RA, Burrin JM, Kohner EM, 1989 Continuous subcutaneous octreotide infusion markedly suppresses IGF-I levels whilst only partially suppressing GH secretion in diabetics with retinopathy. Acta Endocrinol 120: 187-194.

21. Hansson HA, Petruson B, Skottner A, 1986 Somatome$\operatorname{din} \mathrm{C}$ in the pathogenesis of malignant exophthalmos of endocrine origin. Lancet 1: 218-219.
22. Hansson HA, 1989 Aspects on growth factors in exophthalmos. Acta Endocrinol 21: Suppl 2: 107-111.

23. Pasquali D, Vassallo P, Esposito D, Bonavolonta G, Bellastella A, Sinisi AA, 2000 Somatostatin receptor gene expression and inhibitory effects of octreotide on primary cultures of orbital fibroblasts from Graves' ophthalmopathy. J Mol Endocrinol 25: 63-71.

24. Pasquali D, Notaro A, Bonavolonta' G, Vassallo P, Bellastella A, Sinisi AA, 2002 Somatostatin receptor genes are expressed in lymphocytes from retroorbital tissues in Graves' disease. J Clin Endocrinol Metab 87: 5125-5129.

25. Stewart PM, Sheppard MC 1999 Depot long-acting somatostatin analogue (sandostatin-LAR ${ }^{\circledR}$ ) and the treatment of acromegaly. In: Lamberts SWJ (ed) Octreotide: the next decade, Bristol, Bioscientifica; pp, 85-93. 